Available online at GSC Online Press Directory

GSC Biological and Pharmaceutical Sciences

e-ISSN: 2581-3250, CODEN (USA): GBPSC2

Journal homepage: https://www.gsconlinepress.com/journals/gscbps

(RESEARCH ARTICLE)

\title{
Insecticidal activity of essential oils of Chenopodium ambrosioides and Cupressus sempervirens and their binary combinations on Sitophilus zeamais
}

\author{
Langsi D. J. ${ }^{*}$, Tofel H. K ${ }^{2}$, Fokunang C. N. ${ }^{3}$, Suh C. ${ }^{4}$, Eloh K. ${ }^{5}$, Caboni ${ }^{5}$, Nukenine E.N. ${ }^{1}$ \\ ${ }^{1}$ Faculty of Sciences, University of Ngaoundere, Cameroon \\ ${ }^{2}$ Faculty of Science, University of Bamenda, Cameroon \\ ${ }^{3}$ Faculty of Medicine and Biomedical Sciences, University of Yaoundé 1, Cameroon \\ ${ }^{4}$ Institute of Agricultural Research for Development, Nkolbisson-Yaounde, Cameroon \\ ${ }^{5}$ Department of Life and Environmental Sciences, University of Cagliari, Italy
}

Publication history: Received on 19 April 2018; revised on 11 May 2018; accepted on 16 May 2018

https://doi.org/10.30574/gscbps.2018.3.2.0032

\begin{abstract}
Maize is cultivated worldwide and used as food and for fuel production. It is usually attacked and destroyed during storage by Sitophilus zeamais. With inaccessibility to synthetic pesticides, farmers are left with the choice of using locally available plant based pesticides. For this reason, we tested the insecticidal potentials of essential oils (EOs) of Chenopodium ambrosioides and Cupressus sempervirens and their binary combinations against S. zeamais on stored maize. Mortality, progeny inhibition, repellence and damage were tested. Pesticide characteristics of both essential oils were dose-dependent, $200 \mu \mathrm{L} / \mathrm{kg}$ of all the combinations caused at least $80 \%$ mortality within 14 days of storage while the 50:50 combination completely inhibited progeny production. Moreover, $8 \mu \mathrm{L}$ of all the EO were repellent to the weevils. The 50:50 binary combination was the most active in all the tests carried out. Pesticidal interactions between the oils in combination were mostly additive and synergistic. There was also a good control of insect population increase and grain damage after six months of storage. Therefore both EOs can be recommended for the control of S. zeamais.
\end{abstract}

Keywords: Botanical pesticides; Essential oil; Grain damage; Maize insect pests

\section{Introduction}

Food security and poverty reduction are priorities we need to tackle in the Sub-Saharan region with the average amount of food available per person per day of 1,300 calories compared to the worldwide average of 2,700 calories [1]. Food safety crisis in the Sahel, driven by chronic poverty, high food prices, drought and low agricultural production, affect 18.7 million people across the region in 2013 [2]. Agricultural products are on-farm consumed while generating income. Cereals are a major source of food and contribute to about $50 \%$ of the total dietary energy supplies for this region [3]. Maize is the most widely-grown staple food crop in Sub-Sahara Africa (SSA), occupying more than 33 million ha each year with a yield of 70 million tonnes [4]. Importantly, maize is a staple food crop grown in diverse agro-ecological zones and farming systems, and consumed by people with varying food preferences and socio-economic backgrounds in SSA. Its central role as a staple food is comparable to that of rice or wheat in Asia, with consumption rates being the highest in eastern and southern Africa [5]. Cameroon is a country with a strong agricultural economy. Almost $70 \%$ of the active population is involved in agriculture, which contributes to about $25 \%$ of the Gross Domestic Product [3], with 55\% of its rural population involved in agricultural activity, living in extremely poor conditions [6]. Moreover, the practice of agriculture is rendered difficult by the absence of farming

\footnotetext{
${ }^{*}$ Corresponding author

E-mail address: langsijacob@ gmail.com
}

Copyright (C) 2018 Author(s) retain the copyright of this article. This article is published under the terms of the Creative Commons Attribution Liscense 4.0. 
tools, fertilizers, illiteracy, farm to market roads, pest problems, drying and storage facilities [7]. To ensure food security for the whole year, farmers store more than $75 \%$ of their harvested maize and cowpea and they have to protect them from weevil attacks [8]. Therefore, plants with pesticidal characterstics could be used [9]. Chenopodium ambrosioides L. (Amaranthaceae) and Cupressu ssempervirens L. (Cupressaceae) are plants used for insecticidal purposes by local populations in the North-West Region of Cameroon. Ch. ambrosioidesis a plant whose extracts have been studied against S. zeamais Motschulsky for its oviposition suppression, ovicidal and larvicidal effects [10-12]. Tapondjou et al., (2002) evaluated in-vitro toxicity and progeny control effects of both EOs while with $\mathrm{Cu}$. Sempervirens mortality, progeny and repellence effects have been studied on S. zeamais Motschulsky [13-14]. The main objectives of this work were to evaluate the efficacy of EOs of Ch. Ambrosioides and Cu. sempervirens and their binary combinations in the control of $S$. zeamais. We also evaluated their efficacy on insect mortality, progeny production inhibition, repellence and grain damage.

\section{Materials and methods}

\subsection{Plant material}

\subsubsection{Test maize}

The Acid Tolerant Population (ATP) variety of maize was collected from farmers in Big Babanki (North West Region, Cameroon) and identified in the cereals unit of Institute of Agricultural Research for Development (IRAD) Bambui. The water content of maize used in bioassays was evaluated by the [15] method and found to be $12.67 \pm 0.34 \%$. The weevils were obtained from stock cultures from the crop protection laboratory of IRAD, Bambui. Fresh leaves of $C h$. ambrosioides and Cu. sempervirens were collected from IRAD Bambui from December 2015 to February 2016, shade dried, and hand crushed to get powder.

\subsection{Extraction of essential oils by hydrodistillation}

Essential oils were extracted by hydrodistillation of the shade dried powders using a Clevenger apparatus at the Laboratory of Industrial Chemistry and Bio-resources of the National Advanced School of Agro-Industrial Sciences (ENSAI, Ngaoundere). The oils collected were dried on $\mathrm{Na}_{2} \mathrm{SO}_{4}(\mathrm{~s})$, weighed and stored in the dark at $4^{\circ} \mathrm{C}$ in opaque bottles. All bioassays were carried out from May to September 2016.

\subsection{Analysis of chemical composition by GC/MS}

Essential oils were analyzed for component identification using an Agilent Technologies 6850 gas chromatograph coupled with a mass detector 5973 and a 7683B Series Injector autos ampler. The EOs were diluted by adding $1 \mathrm{~mL}$ of hexane to $1 \mu \mathrm{L}$ of oil and $1 \mu \mathrm{L}$ of the sample was injected in splitless mode. The resulting data was elaborated using MSD ChemStation and the NIST deconvolution software AMDIS. The column was 5\% phenylmethylpolysyloxane (30 m x $0.25 \mathrm{~mm}$; film thickness $0.25 \mu \mathrm{m}$ ). Injector temperature was kept at $200{ }^{\circ} \mathrm{C}$. Components were separated in the oven following a temperature gradient starting from $50{ }^{\circ} \mathrm{C}$ and kept for $7 \mathrm{~min}$; then raised to $300{ }^{\circ} \mathrm{C}\left(10{ }^{\circ} \mathrm{C} / \mathrm{min}\right)$ and kept at this temperature for $4 \mathrm{~min}$. Helium was used as carrier gas with a flow of $1.1 \mathrm{~mL} / \mathrm{min}$. The mass detector settings were as follows: ionization voltage, $70 \mathrm{eV}$; scan rate, $2.91 \mathrm{scan} / \mathrm{s}$; mass range, 50-500; transfer line, $230^{\circ} \mathrm{C}$. Essential oil components were identified by:

(a) Comparison of their relative retention times and mass fragmentation with those of authentic standards and

(b) Computer matching against NIST98 library and Golm Metabolome Database (GMD), as well as retention indices as calculated according to Kovats, for alkanes C9-C24 compared with those reported by Adams [16].

\subsection{Insect mortality and progeny control}

Twenty five grams of maize was placed in $500 \mathrm{~mL}$ glass jars. Aliquots of the Ch. ambrosioides (AA), Cu. sempervirens $(\mathrm{AB})$ as binary combinations $(75: 25,50: 50$ and $25: 75)$ were applied at the following concentrations $0 \mu \mathrm{L} / \mathrm{kg}$ (control), 25,$50 ; 100$, and $200 \mu \mathrm{L} / \mathrm{kg}$ (each concentration diluted in $1 \mathrm{~mL}$ acetone to permit distribution on grains). All treatments were replicated 4 times. The maize-essential oil-acetone mixture was then manually shaken. Then, the jars were left open for 45 min to allow complete evaporation of the solvent. Afterwards, 20 unsexed adults, less than 7 days old, were added into each jar and kept on laboratory shelves. Insect mortalities were recorded at 1, 3, 7 and 14 $\mathrm{d}$ after treatment. All tests were carried out at the following conditions: temperature: $17.3-28.8{ }^{\circ} \mathrm{C}$ and relative humidity: 56.3-97.8\%. 


\subsection{Progeny production inhibition assessment}

On the $14^{\text {th }}$ day post-infestation, all the insects left were discarded and the different jars containing grains were kept under the same experimental conditions. The recording of $\mathrm{F}_{1}$ progeny was done once a week for 5 weeks commencing from six weeks after infestation [17].

Percentage reduction in adult emergence (\% IR) was calculated as:

$$
\% I R=\frac{(\mathrm{Cn}-\mathrm{Tn}) \times 100}{\mathrm{Cn}}
$$

Where $C_{n}$ is the number of newly emerged insects in the untreated jar (control) and $T_{n}$ is the number of insects in the treated jar.

\subsection{Repellency test}

The repellence test used was adopted from several authors [18] [19]. Four solutions of 1, 2, 4 and $8 \mu \mathrm{L}$ of essential oils were dissolved in $1 \mathrm{~mL}$ of acetone. Whatman $\mathrm{n} 01$ filter papers were cut into two equal halves and placed inside petri dishes (110 mm diameter). One half of each filter paper was treated with essential oil solution by using a micro pipette. The other half of the filter paper was treated with acetone only. The essential oil treated and acetone treated filter papers halves were air-dried to evaporate the solvent completely. EO treated and acetone treated half-dishes were then attached lengthwise, edge-to-edge with adhesive tape and placed at the bottom in glass petri dish (height $15 \mathrm{~mm} \times$ radius $55 \mathrm{~mm}$ ). Ten adults of insects were released at the centre of the petri dishes and then the petri dishes were covered and kept in the dark. Four replicates were set for each concentration of essential oils. Number of the insects on both treated and untreated halves was recorded every hour for four hours in mild light. The average was then calculated. The percentage repellence (PR) was calculated using the formula by [19] given by:

$$
\mathrm{PR}=2 *(\mathrm{C}-50)
$$

Where: $\mathrm{C}$ is the percentage of insects in the negative control half. The results were interpreted following the scale by [18] (Table 1)

Table 1 Interpretation of percentage repellence [18]

\begin{tabular}{lll}
\hline Class & Repellence rate (\%) & Interpretation \\
\hline X & $>0.01$ to $<0.1$ & Non repellent \\
I & 0.1 to 20 & Very low repellence \\
II & 20.1 to 40 & Low repellence \\
III & 40.1 to 60 & Moderately repellent \\
IV & 60.1 to 80 & Repellent \\
V & 80.1 to 100 & Very repellent \\
\hline
\end{tabular}

\subsection{Damage bioassay}

The mixture essential oils of $C h$. ambrosioides and $C u$. sempervirens of ratios (75:25, 50:50 and 25:75) used in the study. Two doses of these essential oil mixtures, 25 and $200 \mu \mathrm{L} / \mathrm{kg}$ on $100 \mathrm{~g}$ of grain in $1 \mathrm{~L}$ jars were prepared as described earlier. A group of $50(<7 \mathrm{~d}$ old) adult insects of mixed sexes was introduced into each jar containing treated or untreated grain (control in $1 \mathrm{~mL}$ acetone). Each treatment was repeated 3 times. After 6 months, the number of living and dead insects was determined for each jar. Damage assessment was carried out by determining the weight of the grains without powder (final weight) as well as the proportion of grains with holes in 50 randomly selected grains.

Percentage weight loss was determined as follows:

[(initial weight - final weight) $/$ initial weight $] \times 100$. 
Langsi et al. / GSC Biological and Pharmaceutical Sciences 2018, 03(02), 024-034

Grain damage was determined as follows: 100 grains were randomly selected from each jar and the number of damaged (grains with holes) and undamaged grains were counted.

\subsection{Statistical analysis}

Adult mortality was corrected relative to natural mortality in the controls using Abbott's formula [20]. Data on

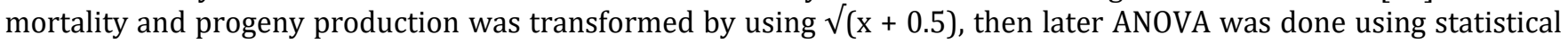
package for social sciences (SPSS) version 20 software. Tukey test (HSD) was used for mean separation. Probit analysis was used to calculate the lethal doses that cause $50 \%$ mortality $\left(\mathrm{LD}_{50}\right)$ after $1,3,7$ and 14 days after treatment.

\section{Results}

\subsection{Chemical composition}

As seen in table 2, with Chenopodium ambrosioides, all compounds identified were hydrogenated monoterpenes with the highest being 4-carene (53\%). With, Cupressus sempervirens, 46 compounds were identified and the hydrogenated monoterpenes $(69.2 \%)$ were dominant followed by the oxygenated monoterpenes $(16.95 \%)$, the hydrogenated sesquiterpenes $(4.21 \%)$ and last by the oxygenated sesquiterpenes $(0.7 \%)$. Of all the compounds identified, 3-carene was the most concentrated (25.91\%) followed by $\alpha$-pinene (17.59\%). Of the oxygenated monoterpenes, terpinen-4-ol was the most concentrated (4.73\%). All sesquiterpenes were below $1 \%$ in concentration. Others were present as trace amounts (less than 0.1\%). With chemical composition, found more elevated proportions of Cymol (50\%) and terpinene (37.6\%) [12]. It is also noted the absence of even trace amounts of ascaridole earlier found in samples [21$22,12]$. This variation in content of volatiles could be explained by geographical locations of the plant. The result of present analysis of $\mathrm{Cu}$. sempervirens essential oil also confirmed the absence of cymol which was shown in previous work of Tapondjou et al., (2005) whereas their study revealed an elevated presence of hydrogenated monoterpenes [14]. A similar chemical composition rich in $\alpha$-pinene (27.5 to $35.8 \%$ ), $\alpha$-cedrol (7.7 to $19.3 \%$ ), $\delta$-3-carene (5.8 to 13.2\%) was found by Ismail et al., (2013) [23]. While Mazari et al., (2003) also found that the majority of the compounds found were hydrocarbon monoterpenes [24].

Table 2 Chemical composition of Ch. ambrosioides essential oil

\begin{tabular}{|c|c|c|}
\hline KI* & Compound Name & Percentage (\%) \\
\hline 1013 & 4-carene & 52.88 \\
\hline 1017 & p-cymene (Cymol) & 29.03 \\
\hline 1035 & $\tau$-terpinene & 1.23 \\
\hline 1227 & 3-carene & 2.12 \\
\hline Total & & 85.26 \\
\hline
\end{tabular}

\subsection{Mortality}

The mortality of S. zeamais by contact upon treatment with essential oils of Ch. ambrosioides and Cu. sempervirens are shown in Table 4. Mortality increased with dose administered and time of exposure. There were also significant differences between the same concentrations of essential oils of both plants in the different periods of exposure. The highest dose of Ch. ambrosioides killed over $90 \%$ of the weevils after $24 \mathrm{~h}$ of exposure against $54 \%$ with $\mathrm{Cu}$. sempervirens. Tapondjou et al., (2005) reported $5 \%$ mortality on $0.2 \mathrm{~mL} / \mathrm{cm}^{2}$ of filter paper in vitro after $24 \mathrm{~h}$ with $S$. zeamais being the least susceptible of all the tested insects to Ch. ambrosioides essential oil [14]. They also reported that Eucalyptus saligna was more active than Cu. sempervirens. Furthermore, Ntonifor et al., (2011) working on powders of Ch. ambrosioides, recorded $100 \%$ mortality of S. zeamais at a dose of $20 \mathrm{~g} / \mathrm{kg}$ [11]. By the $14^{\text {th }} \mathrm{d}$, both insecticides showed appreciable toxicity with more than $80 \%$ of mortality. When applied alone Ch. ambrosioides showed the most efficient insecticidal activity from day 1 to day 14 after infestation. In fact, mortality was at $100 \%$ after $72 \mathrm{~h}$ of treatment. Tapondjou et al., (2005), [14] registered $100 \%$ mortality of S. zeamais after $48 \mathrm{~h}$ in-vitro by using Ch. ambrosioides at a dose of 6.4\%. Terpinen-4-ol is reported as a potent miticide [26]. The toxicity of the volatile oil from Ch. ambrosioides is generally attributed to ascaridole, cymol and a-terpinene [14]. Surprisingly, we did not detect ascaridol in our sample. The toxicity of Ch. ambrosioides on S. zeamais was also reported both as contact powder and as fumigant ethanolic extract of essential oil causing $100 \%$ mortality within $48 \mathrm{~h}$ [10]. 
Table 3 Chemical composition of Cupressus sempervirens essential oil

\begin{tabular}{|c|c|c|}
\hline KI* & Name & $\begin{array}{l}\text { Percentage } \\
\text { (\%) }\end{array}$ \\
\hline & Hydrogenated Monoterpenes & 69.2 \\
\hline 926 & $\alpha$-thujene & 0.34 \\
\hline 935 & $\alpha$-Pinene & 17.59 \\
\hline 977 & Sabinene & 9.42 \\
\hline 1008 & 3-carene & 25.91 \\
\hline 1016 & o-cymene & 1.26 \\
\hline 1019 & limonene & 10.62 \\
\hline 1037 & $\tau$-terpinene & 1.12 \\
\hline 1047 & $\alpha$-terpinene & 0.19 \\
\hline 1050 & Terpinolene & 1.99 \\
\hline \multirow[t]{2}{*}{1052} & p-cymenene & 0.76 \\
\hline & Oxygenated Monoterpenes & 16.95 \\
\hline 1057 & Linalol & 0.98 \\
\hline 1069 & trans-p-menth-2-en-1-ol & 0.37 \\
\hline 1077 & cis-p-menth-2-en-1-ol & 0.41 \\
\hline 1083 & Eucarvone & 0.22 \\
\hline 1090 & Umbellulone & 3.28 \\
\hline 1095 & terpinen-4-ol & 4.73 \\
\hline 1201 & p-menth-1-en-8-ol & 1.46 \\
\hline 1209 & cis-piperitol & 0.14 \\
\hline 1217 & 6-Octen-1-ol, 3,7-dimethyl & 0.21 \\
\hline 1218 & thymol methyl ether & 0.36 \\
\hline 1231 & Verbenone & 0.27 \\
\hline 1233 & 5-decen-1-ol & 0.49 \\
\hline 1235 & Piperitone & 0.57 \\
\hline 1249 & isobornyl acetate & 0.14 \\
\hline 1263 & propanoic acid, 2-octyl ester & 0.27 \\
\hline 1281 & $\alpha$-terpineolacetate & 2.97 \\
\hline \multirow[t]{2}{*}{1421} & borneol, butyrate & 0.08 \\
\hline & Hydrogenated Sesquiterpenes & 4.21 \\
\hline 1428 & d-longifolene & 0.08 \\
\hline 1444 & epi-bicyclosesquiphellandrene & 0.21 \\
\hline 1453 & $\delta$-cadinene & 0.13 \\
\hline 1456 & epi-bicyclosesquiphellandrene & 1.32 \\
\hline 1464 & Curcumene & $\operatorname{tr}$ \\
\hline 1469 & $\alpha$-farnesene & 0.08 \\
\hline 1476 & $\alpha$-elemane & 0.46 \\
\hline 1488 & Bicyclo[4.4.0]dec-1-ene, 2-isopropyl-5-methyl-9-methylene & 0.11 \\
\hline 1490 & $\delta$-cadinene & 0.32 \\
\hline 1493 & calamenene & 0.45 \\
\hline 1903 & $(5,9 \alpha-, 10 \beta)$-kaur-15-ene & 0.86 \\
\hline 2042 & Abietatriene & $\operatorname{tr}$ \\
\hline \multirow[t]{2}{*}{1886} & kaur-15-ene & 0.19 \\
\hline & Oxygenated Sesquiterpenes & 0.7 \\
\hline 1621 & Spathulenol & 0.06 \\
\hline 1624 & caryophyllene oxide & 0.25 \\
\hline 1636 & Cubenol & 0.15 \\
\hline 1652 & $\alpha$-cadinol & 0.24 \\
\hline 1867 & Rimuene & $\operatorname{tr}$ \\
\hline \multirow[t]{2}{*}{2032} & Phyllocladen & $\operatorname{tr}$ \\
\hline & Total & 91.34 \\
\hline
\end{tabular}

$\operatorname{tr}(<0.1 \%) ;{ }^{*}$ KI: Kovats Index 
Table 4 Mortality (Mean \pm S.E) of $S$. zeamais on treated ATP maize grains with binary combinations of essential oils of Ch. ambrosioidesand Cu. sempervirens.

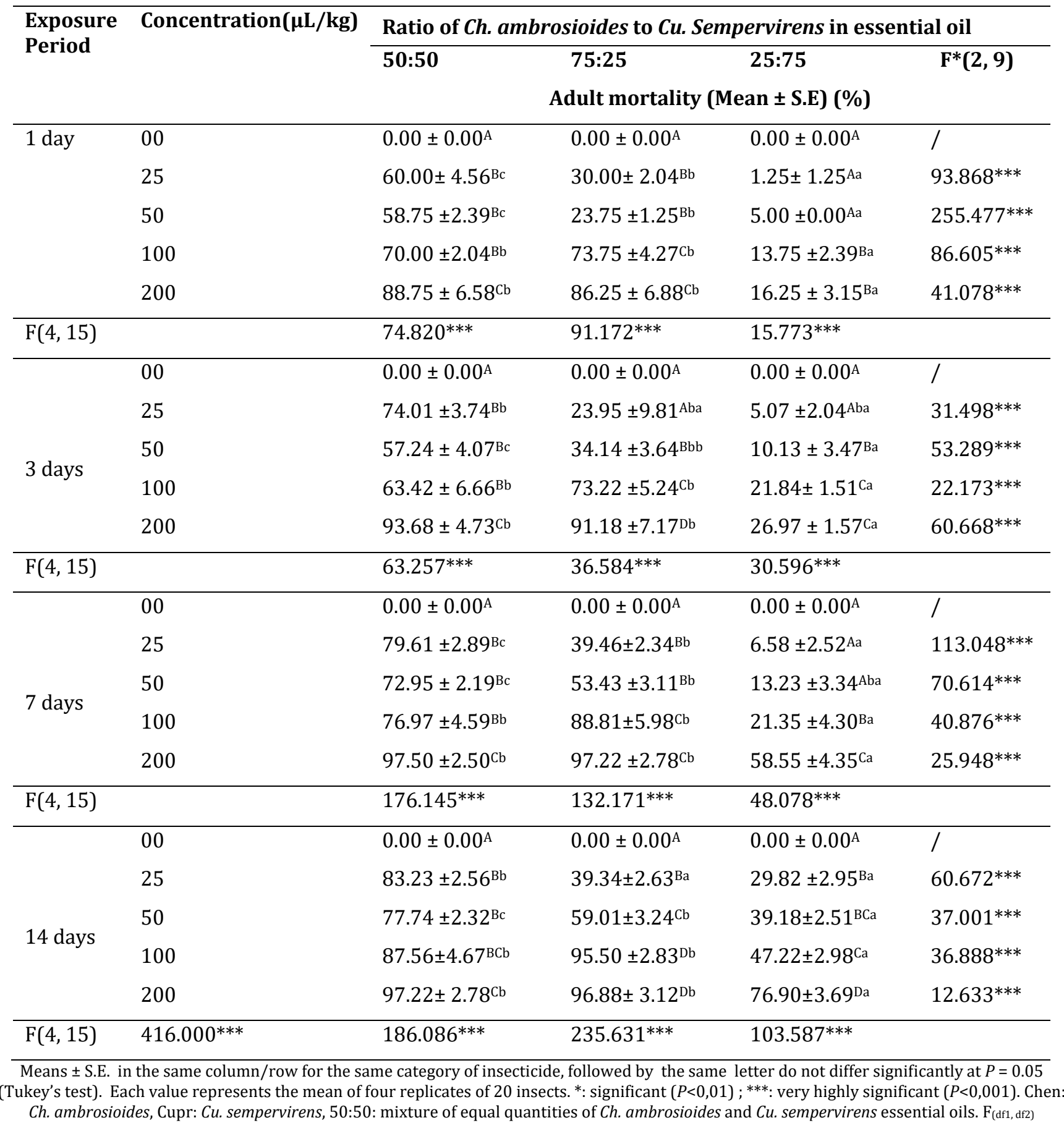

\subsection{Pesticidal interactions}

Insecticidal activity of EOs and their combinations are reported in Table 5. Synergistic effects were observed for binary combination (25:75). Cupressus, being a low toxicity product had its toxic power enhanced by combining it with just 25\% Chenopodium (Table 5). Additive effects were observed on the $7^{\text {th }}$ day post exposure between the 50:50 combination and $75 \%$ Chenopodium. With synergistic and additive effects, it has been proven that combinations of insecticidal materials have the advantages to increase the efficacy by complementing the bio-efficacy of the individual products and simultaneously lowering their use on the one hand and broadening the spectrum of activity and overcoming pest resistance to individual pesticide [25]. 
Table 5 Pesticidal interactions between binary combinations of Essential Oils of Ch. ambrosioides and Cu. sempervirens on S. zeamais

\begin{tabular}{|c|c|c|c|c|c|}
\hline $\begin{array}{l}\text { Ratio of } C h \text { ambrosioides to } C u \text {. } \\
\text { sempervirens in essential oil }\end{array}$ & LC $_{50}$ & $\mathrm{LC}_{95}$ & ${ }^{*}$ Co-tox. Ind & Significance & General X ${ }^{2}$ \\
\hline \multicolumn{6}{|l|}{1 Day } \\
\hline $50: 50$ & 42.96 & 777.79 & 22.34 & Antagonistic & $1922.463^{* * *}$ \\
\hline $75: 25$ & 29.99 & 62.64 & 33.21 & Antagonistic & $706.252^{* * *}$ \\
\hline $25: 75$ & 4.70 & 14.98 & 197.09 & Synergistic & $1058.937^{* * *}$ \\
\hline \multicolumn{6}{|l|}{3 Days } \\
\hline $50: 50$ & 44.21 & 800.33 & 27.83 & Antagonistic & \\
\hline $75: 25$ & 34.95 & 73.01 & 32.48 & Antagonistic & \\
\hline $25: 75$ & 8.27 & 26.38 & 162.31 & Synergistic & \\
\hline \multicolumn{6}{|l|}{7 Days } \\
\hline $50: 50$ & 52.64 & 953.04 & 86.46 & Additive & \\
\hline $75: 25$ & 49.32 & 103.02 & 88.43 & Additive & \\
\hline $25: 75$ & 9.98 & 31.82 & 75.36 & Antagonistic & \\
\hline \multicolumn{6}{|l|}{14 Days } \\
\hline $50: 50$ & 56.90 & 1030.08 & 73.91 & Antagonistic & \\
\hline $75: 25$ & 52.33 & 114.61 & 79.43 & Antagonistic & \\
\hline $25: 75$ & 32.14 & 102.51 & 132.39 & Synergistic & \\
\hline
\end{tabular}

\subsection{Progeny inhibition}

Data on the progeny emergence experiments is reported on Table 6. The highest doses of both essential oils gave $>90 \%$ inhibition. There were very high significant differences in the percentage reduction in progeny production between all the doses administered for both plants. All products were good progeny production inhibitors with very high significant differences. C. ambrosioides gave 100\% progeny production inhibition at its highest dose. These results are in agreement with those of Tapondjou et al., (2002; 2005) also found good progeny control properties of Cu. sempervirens [12] [14].

Table 6 Percent reduction of progeny (Mean \pm S.E) of Sitophilus zeamais on maize grains treated with mixture of essential oils of Chenopodium ambrosioides and Cupressus sempervirens.

\begin{tabular}{|c|c|c|c|c|c|c|}
\hline \multirow{3}{*}{$\begin{array}{l}\text { Treatment } \\
\text { Concentration } \\
(\mu \mathrm{L} / \mathrm{kg})\end{array}$} & \multicolumn{6}{|c|}{ Ratio of Ch. ambrosioides to Cu. Sempervirensin essential oil } \\
\hline & \multicolumn{2}{|l|}{$50 / 50$} & \multicolumn{2}{|l|}{$75: 25$} & \multicolumn{2}{|l|}{$25: 75$} \\
\hline & Progeny & $\begin{array}{l}\% \text { reduction } \\
\text { of Progeny }\end{array}$ & Progeny & $\begin{array}{l}\% \text { reduction } \\
\text { of Progeny }\end{array}$ & Progeny & $\begin{array}{l}\% \text { reduction } \\
\text { of Progeny }\end{array}$ \\
\hline 00 & $42.00 \pm 1.41^{\mathrm{C}}$ & $0.00 \pm 0.00^{\mathrm{A}}$ & $42.25 \pm 1.31^{\mathrm{C}}$ & $0.0 \pm 0.00^{\mathrm{A}}$ & $40.00 \pm 0.41^{\mathrm{E}}$ & $0.00 \pm 0.00^{\mathrm{A}}$ \\
\hline 25 & $13.25 \pm 1.11^{\mathrm{B}}$ & $68.37 \pm 2.86^{B}$ & $22.7 \pm 1.38^{B}$ & $45.85 \pm 4.25^{\mathrm{B}}$ & $17.75 \pm 0.63^{\mathrm{D}}$ & $55.64 \pm 1.34^{\mathrm{B}}$ \\
\hline 50 & $10.00 \pm 0.41^{\mathrm{B}}$ & $76.16 \pm 0.84^{C}$ & $12.25 \pm 0.62^{\mathrm{A}}$ & $70.84 \pm 2.11^{\mathrm{C}}$ & $9.25 \pm 0.75^{\mathrm{C}}$ & $76.90 \pm 1.76^{C}$ \\
\hline 100 & $0.75 \pm 0.48^{\mathrm{A}}$ & $98.21 \pm 1.19^{D}$ & $8.75 \pm 0.75^{\mathrm{A}}$ & $79.29 \pm 1.72^{\mathrm{C}}$ & $5.75 \pm 0.48^{\mathrm{B}}$ & $85.59 \pm 1.34^{\mathrm{D}}$ \\
\hline 200 & $0.00 \pm 0.00^{\mathrm{A}}$ & $100 \pm 0.00^{\mathrm{D}}$ & $8.00 \pm 0.71^{\mathrm{A}}$ & $81.06 \pm 1.66^{C}$ & $0.75 \pm 0.25^{\mathrm{A}}$ & $98.11 \pm 0.63^{\mathrm{E}}$ \\
\hline$F_{(4,15)}$ & $403.078^{* * *}$ & $806.257^{* * *}$ & $203.127^{* * *}$ & $204.814^{* * *}$ & $841.588^{* * *}$ & $1050.092^{* * *}$ \\
\hline
\end{tabular}




\subsection{Repellence}

Table 7 shows the in vitro repellence EO activity in the various treatments. Generally, the $8 \mu \mathrm{L} / \mathrm{kg}$ dose was the most repellent with repellence indices greater than 60\%. Ch. ambrosioides however was more repellent than $\mathrm{Cu}$. sempervirens at all the doses administered. Appreciable ovicidal and lavicidal effects of powders of Ch. ambrosioides and $C$. sempervirens against $S$. zeamais have also been proven $[11,14]$. Earlier literature showed a repellence activity of $C$ u. sempervirens greater than cymol [14].

Table 7 In-vitro repellency (Mean \pm S.E) of Sitophilus zeamais on filter paper due to treatment with essential oils of Ch. ambrosioides and $\mathrm{Cu}$. sempervirens

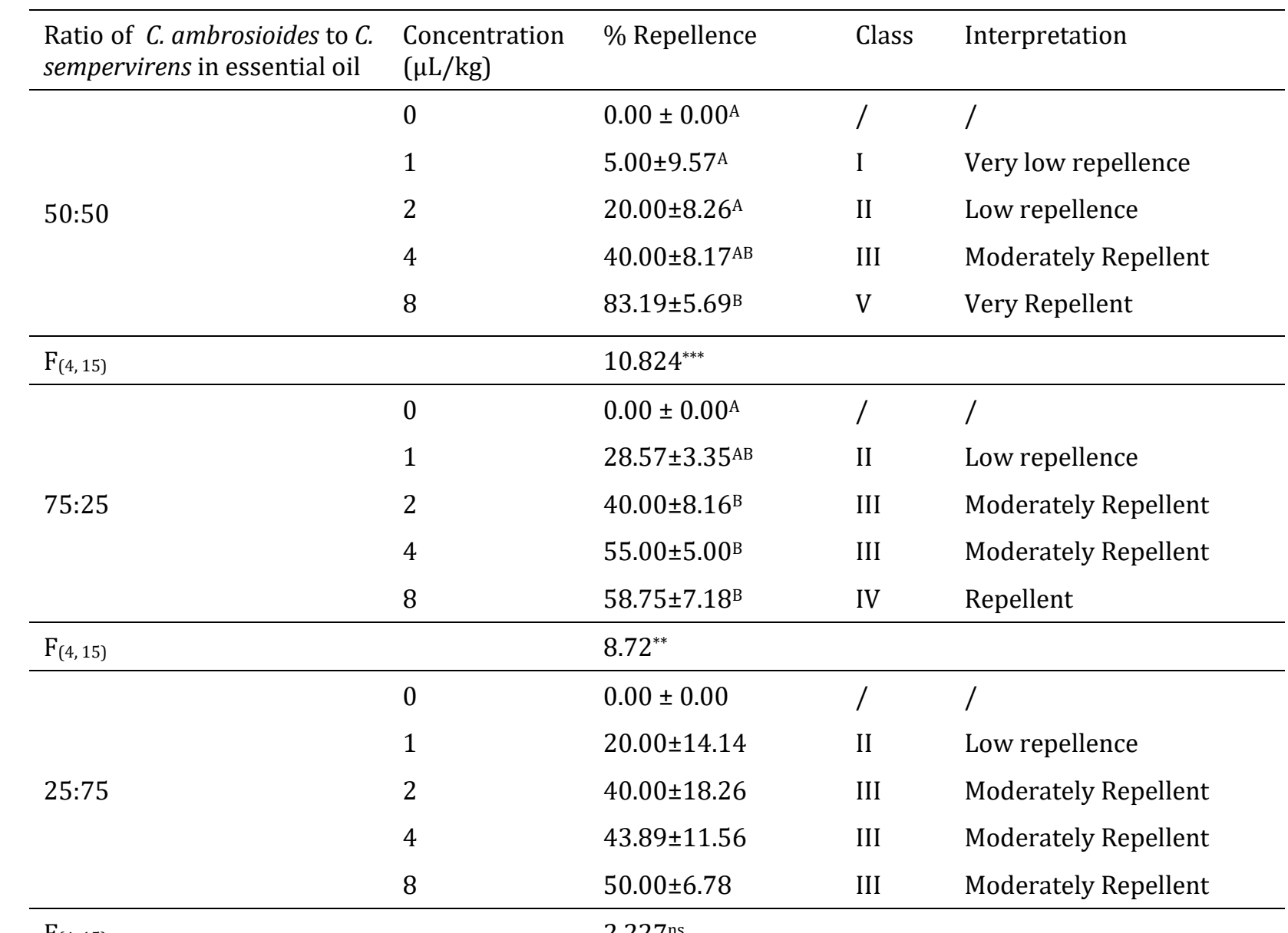

$\mathrm{F}_{(4,15)} 2.227^{\mathrm{ns}}$

Means \pm S.E. in the same column for the same category of insecticide, followed by the same letter do not differ significantly at $P=0.05$ (Tukey's test). Each value represents the mean of four replicates of 10 insects each. ${ }^{* *}$ : very significant $(\mathrm{P}<0.01)$. ). Chen: Ch. ambrosioides, Cupr: and Cu. sempervirens essential oils. $\mathrm{F}_{(\mathrm{df} 1, \mathrm{df} 2)}$

\subsection{Population increase and damage control}

Population increase was evaluated counting the number of new insects that emerged from the initial 50 that were introduced into the treated jars. For dead insects, after 6 months of storage, the highest doses gave a non-significantly different average value of 50 with all the EOs while the lower doses also gave about 40 dead insects (Table 8). The notable difference came with the number of living insects present. With high significant differences, the $25 \mu \mathrm{L} / \mathrm{kg}$ content of $75 \%$ Ch. ambrosioides was the least toxic (more than 600) while with the $200 \mu \mathrm{L} / \mathrm{kg}$ content, $75 \% \mathrm{Cu}$. sempervirens was the least toxic. The best results were observed for the 50:50 binary combinations of EOs.

It was noted significant differences between the different fractions of the different essential oils at all the contents administered but very significantly different between the different contents of the same essential oil. With grain weight loss, the $50: 50$ binary combination was the best with $2 \%$ followed by $100 \%$ Ch. ambrosioides with $3 \%$. With percentage of grains with holes, the $50: 50$ binary combination gave $2 \%$ also followed by the $75 \%$ Ch. ambrosioides and least by the $100 \% \mathrm{Cu}$. sempervirens. We noticed visible positive effects between the combinations of both oils: especially with respect to $\mathrm{Cu}$. Sempervirens. 
Langsi et al. / GSC Biological and Pharmaceutical Sciences 2018, 03(02), 024-034

Table 8 In-vivo damage control (Mean \pm S.E) of Sitophilus zeamais on maize due to treatment with essential oils of Chenopodium ambrosioides and Cupressus sempervirens and their binary combinations

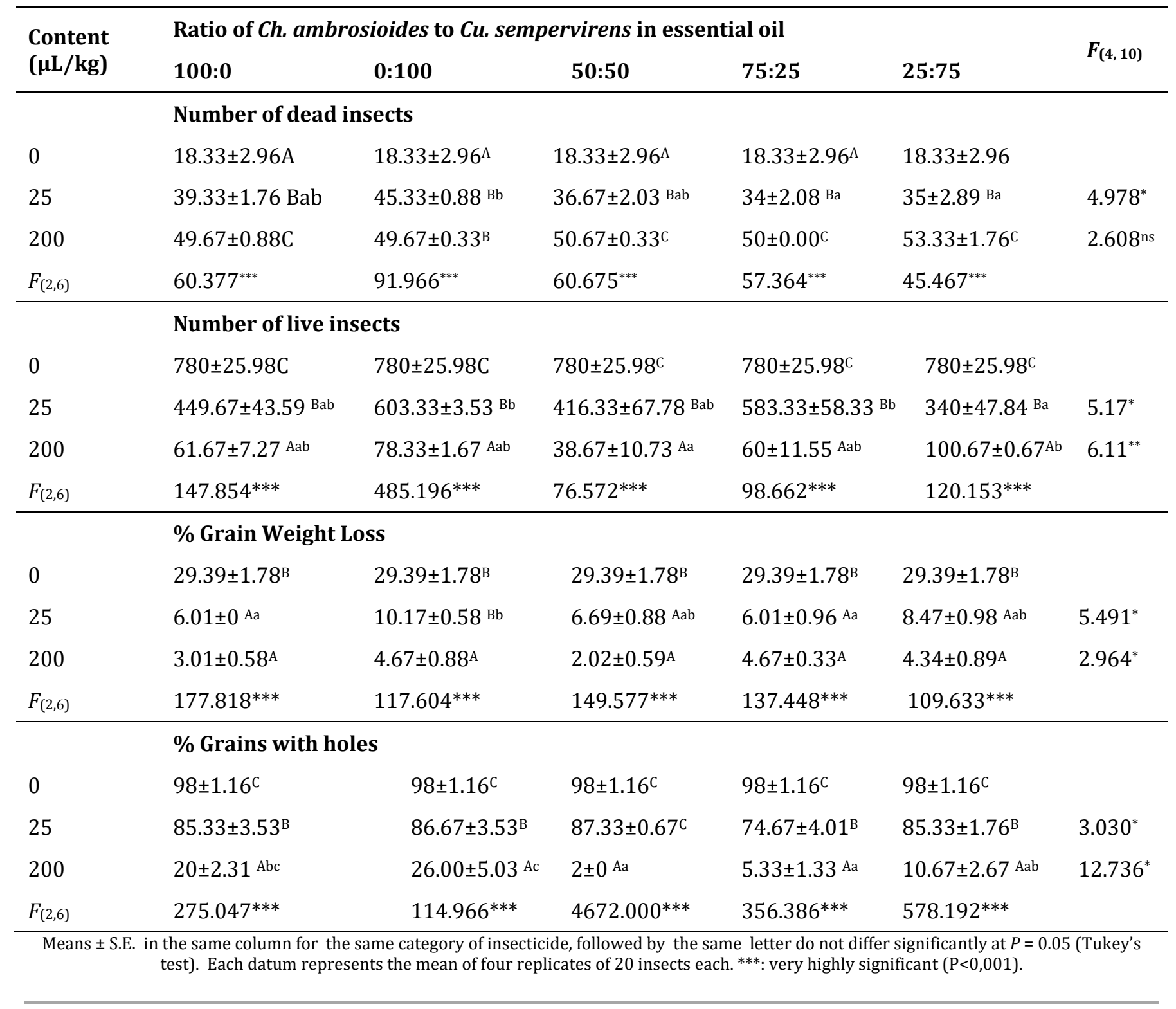

\section{Conclusion}

The binary combinations of the essential oils of $C$. ambrosioides and Cu. sempervirens tested on maize were very efficient insecticides against the maize weevils. These potentials to control the proliferation of $S$. zeamais in stored maize was also dose dependent and increased with period of exposure. Therefore both EOs can be recommended for their insecticidal, progeny control effects, high repellence and ability to prevent grain from damage caused by maize weevils and can be easily used in an integrated pest management practice.

\section{Compliance with ethical standards}

\section{Acknowledgments}

Deep gratitude goes to the entire staff of IRAD Bambui (Bamenda) for the provision of work space for laboratory manipulations as well as to the laboratory of Industrial Chemistry and Bio-resources of ENSAI, Ngaoundere for providing the necessary resources for the extraction of the essential oils. Some of the equipment used to carry out the research were purchased with financial assistance from the Alexander-Von-Humboldt Foundation, Bonn, Germany under grant number 3.4-B151/11016 (Equipment grant) to E.N Nukenine. 


\section{Disclosure of conflict of interest}

The author of this work and all co-authors attest to the fact that no part of this work is a product of plagiarism. All previously authored works used in this paper are backed with references. Hence there exists no conflict of interest.

\section{References}

[1] Godfray HG, Beddington JR, Crute IR, Haddad L, Lawrence D, Muir JF, Pretty J, Robinson S, Thomas SM, Toulmin C. (2010). Food security: the challenge of feeding 9 billion people. Science, 327(5967), 812-818.

[2] Food and Agriculture Organization of the United Nations. (2013). FAO's Response to the 2012 Sahel Crisis. FAO, Rome.

[3] FAO A. (2008). Introduction to the basic concepts of food security. FAO, Rome, Italy.

[4] (FAOSTAT) (2015). Food and Agriculture Organization of the United Nations. Statistics Division, 04 October 2015.

[5] Macaule, H and Ramadjita T. (2015). Cereal crops: Rice, maize, millet, sorghum, wheat. Feeding Africa, 36.

[6] Ntsama SM and Kamgnia Dia B. (2008). Determinants of the adoption of improved varieties of Maize in Cameroon: case of cms 8704. University Library of Munich, Germany. Proceedings of the African Economic Conference, 17, 397- 413.

[7] Manu IN, Tarla DN, Chefor GF, Ndeh EE and Chia I. (2015). Socio-economic analysis and adoption of improved maize (Zea mays L.) varieties by farmers in the North West Region of Cameroon. Asian Journal of Agricultural Extension, Economics and Sociology, 4(1), 58-66.

[8] Tofel KH, Nukenine EN, Stähler M and Adler C. (2016). Degradation of azadirachtin A on treated maize and cowpea and the persistence of Azadirachta indica seed oil on Callosobruchus maculatus and Sitophilus zeamais. Journal of Stored Products Research, 69, 207-212.

[9] Napoleão TH, do Rego Belmonte B, Pontual EV, de Albuquerque LP, Sá RA, Paiva LM Coelho LC and Paiva PM. (2013). Deleterious effects of Myracrodruon urundeuva leaf extract and lectin on the maize weevil, Sitophilus zeamais (Coleoptera, Curculionidae). Journal of stored products research, 54, 26-33.

[10] Denloye A, Makanjuola W, Teslim O, Alafia O, Kasali A and Eshilokun A. (2010).Toxicity of Chenopodium ambrosioides L. (Chenopodiaceae) products from Nigeria against three storage insects. Journal of Plant Protection Research, 50(3), 379-384.

[11] Ntonifor NN, Forbanka DN and Mbuh JV. (2011). Potency of Chenopodium ambrosioides powders and its combinations with wood ash on Sitophilus zeamais in stored maize. Journal of Entomology, 8(4), 375-383.

[12] Tapondjou LA, Adler CL, Bouda H, Fontem DA. (2002). Efficacy of powder and essential oil from Chenopodium ambrosioides leaves as post-harvest grain protectants against six-stored product beetles. Journal of Stored Products Research, 38(4), 395-402.

[13] Tange AD and Anoh NM. (2015). Bioactivity of cypress leaf powder (Cupressus macrocarpa) on cowpea weevil (Callosobruchus maculatus Fabr. Coleoptera: Bruchidae) and maize weevil (Sitophilus zeamais Motschulsky, Coleoptera: Curculionidae) in stored maize grains in Cameroon. International Journal of Interdisciplinary and Multidisciplinary Studies (IJIMS), 2(4), 1-10.

[14] Tapondjou AL, Adler C, Fontem DA, Bouda H and Reichmuth CH. (2005). Bioactivities of cymol and essential oils of Cupressus sempervirens and Eucalyptus saligna against Sitophilus zeamais Motschulsky and Tribolium confusum du Val. Journal of Stored Products Research, 41(1), 91-102. •

[15] Agence Français de Normalisation (AFNOR). (1982). Recueil de normes franc aise des produits dérivés des fruits et légumes. Association franc , aise de normalisation, $1^{\text {st }}$ edition. AFNOR, Paris. 27 p.

[16] Adams RP. (2007). Identification of essential oil components by gas chromatography/mass spectrometry. Allured Publishing Corporation, Carol Stream, IL, 60188, USA, 469 pp.

[17] Nukenine EN, Adler C and Reichmuth C. (2007). Efficacy evaluation of plant powders from Cameroon as postharvest grain protectants against the infestation of Sitophilus zeamais Motschulsky (Coleoptera: Curculionidae). Journal of plant Diseases and Protection, 114(1), 30-36. 
[18] McDonald LL, Guyr H and Speire RR. (1970). Preliminary evaluation of new candiolate materials as toxicants, repellent and attracts against stored product insect. Marketing Research. 189p.

[19] Talukder FA and Howse PE. (1995). Evaluation of Aphanamixis polystachya as a source of repellents, antifeedants, toxicants and protectants in storage against Tribolium castaneum (Herbst). Journal of Stored Products Research, 31(1), 55-61.

[20] Abbott WS. (1987). A method of computing the effectiveness of an insecticide. Journal of the American Mosquito Control Association (USA), 18, 266-267.

[21] Al-kaf AG, Crouch RA, Denkert A, Porzel A, Al-Hawshabi OS, Ali NA, Setzer WN and Wessjohann L. (2016). Chemical composition and biological activity of essential oil of Chenopodium ambrosioides from Yemen. American Journal of Essential Oils and Natural Products, 4(1), 20-22.

[22] Sá RD, Galvão MA, Ferreira MR, Soares LA and Randau KP. (2014). Chemical composition of the essential oil from leaves of Chenopodium ambrosioides L. grown in Recife-PE, Brazil. Rev. Bras. Farm, 95, 855-866.

[23] Ismail A, Lamia H, Mohsen H, Samia G and Bassem J. (2013). Chemical composition, bio-herbicidal and antifungal activities of essential oils isolated from Tunisian common cypress (Cupressus sempervirens L.). Journal of Medicinal Plants Research, 7(16), 1070-1080.

[24] Mazari K, Bendimerad N and Bekhechi C. (2010). Chemical composition and antimicrobial activity of essential oils isolated from Algerian Juniperus phoenicea L. and Cupressus sempervirens L. Journal of Medicinal Plants Research, 4(10), 959-964.

[25] Das SK. (2014). Scope and relevance of using pesticide mixtures in crop protection: a critical review. International Journal of Environmental Science and Toxicology, 2(5), 119-123.

\section{How to cite this article}

Langsi DJ, Tofel HK, Fokunang CN, Suh C, Eloh K, Caboni P and Nukenine EN. (2018). Insecticidal activity of essential oils of Chenopodium ambrosioides and Cupressus sempervirens and their binary combinations on Sitophilus zeamais. GSC Biological and Pharmaceutical Sciences, 3(2), 24-34. 